\title{
Perioperative Surgical Home. Meeting tomorrow's challenges
}

\author{
Teodora O. Nicolescu
}

Department of Anesthesiology, Oklahoma Health Sciences Center, Oklahoma City, OK, USA

\begin{abstract}
New healthcare models pose a variety of changes for anesthesiologists, ranging from the need to improve quality and to cost containment: as such, the concept of Perioperative Surgical Home (PSH) has been developed. Modelled after the UK's Enhanced Recovery After Surgery (ERAS), PSH takes a step further by coordinating care starting from the time a surgical decision is made for the patient to as many as 30 days postoperatively, taking a logical evidenced-based approach to judicious preoperative testing. Perioperative surgical home also relies heavily on engineering imported strategies such as the use of Lean Six Sigma methodologies, and involves active participation of all stakeholders. By comparison, ERAS is a series of well-defined clinical protocols that do not extend beyond the episode of surgical care. As an added aspect of its benefits, PSH also helps to control costs by decreasing unnecessary testing and cancellations, and allowing for more OR access by inpatients.
\end{abstract}

Keywords: enhanced recovery, perioperative surgical home, blood and fluid management, pain control

Rom J Anaesth Int Care 2016; 23: 141-147

\section{Introduction}

Over the past five years, the role of the anesthesiologist perceived as mainly OR based, with an extension in the critical care environment, has begun to change. At the heart of the change are multiple factors, ranging from better quality of care for patients to economics - mostly cost containment. In addition, rapid technological advancements, automation, the use of iCloud and 3D technology perioperatively in robotic and neurosurgical procedures, have altered the delivery of healthcare. These advances have led to a need to change the practice of Anesthesiology in order to improve patient satisfaction, deliver more timely care, and lower costs. Areas most impacted by the change in the United States would be: length of stay, readmissions, and financial incentives currently in place to

Adress for correspondence:

Teodora O. Nicolescu, MD, MBA, HCM Associate Professor

Department of Anesthesiology Oklahoma Health Sciences Center $750 \mathrm{NE} 13^{\text {th }}$ St., Suite 200 Oklahoma City, OK 73104 USA E-mail: Teodora-Nicolescu@ouhsc.edu provide surgery, and the current costs and rates for postoperative complications.

Perioperative surgical home (PSH) is a physicianbased model aiming to reduce system variability that considers the fundamental concept of healthcare as a continuum (healthcare should not be divided in silos). Perioperative surgical home is considered the model instrumental in the transition from volume to value, and key in the bundle payments system, which are fixed payments for all services during an episode of care. Since historically anesthesiologists have not taken care of patients beyond the perioperative settings, the new model will require the development of a set of skills that includes team building, patient management techniques and lean six sigma methodologies, as well as the development of postoperative care skills. Due to their ability to be system thinkers, since not only do they integrate preoperative, intraoperative and postoperative patient plans, but also have a global view of the patient through the episode of care, anesthesiologists are best positioned to lead those new specialized service line units. Of course there are also challenges to be met such as lack of reimbursement for the services provided, which may change as transition to bundle payments is finalized. However, there is encouragement to be derived from the implementation 
of the Enhanced Recovery After Surgery (ERAS) program in the United Kingdom that has estimated annual savings of $\$ 630$ mil.) [1]. While there is no definitive evidence of improved outcomes as of yet, the initial frontier certainly provides hope.

The bundle payments, regardless of the cost incurred, shifts a lot of attention to outcome measures and the patient's length of stay. The key concepts of the PSH are a focus on patient engagement and early prehabilitation (four areas of improvement: breathing (smoking cessation), movement (exercise), healthy eating, stress reduction), as well as having a clear set date of surgery. Modelled after ERAS, PSH is taking a step further by incorporating the 20 steps of ERAS (6 preoperative measures, 6 intraoperative and 8 postoperative measures) and assuming perioperative coordination of care. Extending the care to 30 days postoperatively, PSH makes the patients an active participant in their care.

There are a few main areas that lend themselves specifically to PSH management. Anemia is present in $5-75 \%$ of the surgical population due to a variety of causes that include the presence of proinflammatory cytokines in aging individuals which suppress erythropoietin production or receptor function, iron, vitamin B12 and folate deficiency, and the presence of chronic disease. Preoperative anemia has been independently associated with an increase in 30-90 day mortality [2]. Aside from the increased risks associated with perioperative cardiac events and renal and central nervous system adverse outcomes, a haematocrit of under $30 \%$ in patients over 50 years old undergoing major elective non cardiac surgery is an independent predictor of postoperative delirium, as cited by Marcanto et al. [3].

Perioperative optimization is therefore paramount in patients undergoing elective surgeries, usually achieved with a regimen of iron (oral and IV), vitamin supplementation, and erythropoiesis stimulating therapy. The cornerstone of the approach is early identification of haemoglobin levels, the optimal time being 28 days before the date of surgery. The Network for Advancement of Transfusion Alternatives (NATA) has established a layered approach that considers different treatments based on the presence of anemia at 28 days before the surgery date, blood levels of iron, folate, and vitamin B12, renal function, and presence of chronic disease (where erythropoietin stimulating therapies are beneficial). Regimens vary considerably among institutions in the United States. For example, The University of Alabama at Birmingham employs a regimen that administers $40000 \mathrm{U}$ of erythropoietin plus $200 \mathrm{mg}$ sucrose IV at days 14 and 7 before the surgery date [4].

Based on the NATA approach, Na et al. cited a decrease in postoperative transfusions at 6 weeks in knee replacement surgeries. Since PSH integrates preoperative, intraoperative, and postoperative care, it also addresses the next step, the intraoperative blood conservation issue [5].

\section{Blood transfusion strategy}

Blood conservation and usage-factoring in overhead, labour and adverse events drives the original price of a unit of blood up to $\$ 2,250$ from an original price of $\$ 240$ [6]. This makes perioperative measures to reduce transfusion instrumental.

In order to prevent waste the American Board of Internal Medicine has established a foundation whose initiative, Choosing Wisely has the goal to advance a national dialogue in order to avoid unnecessary medical tests, treatments and procedures [7]. Following up on recommendations from the Choosing Wisely initiatives in the US, that have been vetted by seven separate specialty societies, employing judicious blood management techniques for patients enrolled in PSH aims to decrease waste by following agreed upon guidelines (no transfusion in young, healthy patients without ongoing blood loss or a low haemoglobin unless symptomatic or hemodynamically unstable).

Keeping in mind that blood transfusions account for $12-21 \% \%$ of inpatient transfusions in hip arthroplasties only [8], the most common postoperative procedure, it is easy to understand the substantial benefits of judicious blood management. Interestingly enough, a surprising number of patients enrolled in PSH were found to be more anemic than originally thought. An example of that is that $40 \%$ of the total hip replacements were found to need on average a $2.8 \mathrm{U}$ of blood preoperatively [9], which was an unexpected finding that led to the establishment of protocols to have anemia investigated by the primary care physician, and haemoglobin of $8 \mathrm{mg} / \mathrm{dl}$ as a trigger to start transfusion of $1 \mathrm{U}$ and then continuously revaluate the need for more.

\section{Medication error prevention}

Aside from judicious blood management, medication error decrease is a mainstay of the $\mathrm{PSH}$, accomplished by integrating and reconciling all the medication for the patient. Medication errors are linked to a minimum of 1 in 5 preventable readmissions [10]. Partnership for patients, a patient centred focus group, has set as their goal to decrease preventable medication errors requiring readmissions by $20 \%$ in 2016 as compared to 2010 making medication error prevention an utmost priority [11]. This is reinforced by other statistics with Centres for Medicare and Medicaid reporting that $13.6 \%$ of all readmissions are medication errors within 30 days postoperatively, costing over 15 billion dollars spent by Medicare annually (\$7200/episode of care) [10]. 
The medications most commonly involved in error are, in order of most common to least common: antibiotics, corticosteroids, cardiovascular drugs, analgesics, and anticoagulants. Most errors are related to incomplete medication reconciliation, medication noncompliance, and poor discharge/planning. By integrating care at the level of the PSH, a substantial decrease of those errors is expected. The perioperative arena is the least redundant area particularly due to the speed with which the patient condition can change, so double or triple checking of medications is not as layered as inpatient medication administration. For example, in inpatient wards any medication administration follows a process with multiple safety stops: the prescribing physician, the pharmacist, the administering nurse and if implemented, the bar coding system. However, in the perioperative environment where there is a mix of elective, urgent/emergent, and rapid change in patient's condition there is great potential for medication reconciliation errors. Having the added safety layer of the perioperative surgical home helps prevent such potential errors. In their March 2015 Patient Safety Primer section, the Agency for Healthcare Research and Quality deemed that most medication errors are happening in either the prescribing or transcribing stages [12]. The perioperative surgical home model directly addresses those stages of errors. One such example is the optimization of beta blocker medication in vascular surgery. A study by Lindenauer et al. from 2005 [13] demonstrated that beta blockade initiation in patients who undergo vascular surgery has to be individualized and specific in high risk patients undergoing major non cardiac surgery since this is the only group where the study demonstrated a reduced risk of in hospital death. Perioperative Surgical Home can not only identify, but also work towards the optimization of such individual regimens. The large aging segment of the population (the baby boomers) who have multiple comorbidities will be in need of operative services over the coming decades, thus placing a high demand on hospital occupancy and costs. Consider the following statistics: $32 \%$ of Americans over the age of 65 undergo surgery one year before their death and 25\% of Medicare spending occurs in the last year of life [14]. By 2020 it is estimated that 157 million will have at least 1 chronic disease and 81million will have multiple such conditions. Both the rise in age and prevalence of chronic disease increase surgical mortality [15]. Elderly patients are a heterogeneous group that need individualized care that takes into account not the only chronological age but also the physiological and functional status of each individual. Equally important, patients in this age group are at a risk of postoperative delirium, and as Leung et al. showed in their study, identification of high risk patients based on the presence of preoperative cognitive dysfunction, a history of central nervous system dysfunction, and a higher surgical risk as well as in particular spine and arthroplasty surgeries, makes the PSH the gatekeeper for the early planning of a multimodal therapy that involves the use of non-opioid analgesics, regional anesthesia, and minimal opioids intra and postoperatively, thus decreasing the length of stay as well as effectively managing the level of pain in those patients [16]. This combined with the CMS's new reimbursement methods that penalize for 30 days' readmission, makes it readily apparent that medication reconciliation, decreased length of stay, and discharge planning must be a priority, a task that the perioperative surgical home can help facilitate.

\section{Pain therapy}

While multimodal pain therapy (ketamine, pregabalin, gabapentin, clonidine, dexmedetomidine) is used in many hospital settings, what gives PSH an advantage is the early identification of patients considered to be a high risk for pain control, and establishing preoperatively customized plans. This includes but is not limited to, optimizing narcotic use for chronic pain patients, prescribing preoperative activities that will aide in the patient's rehabilitation postoperatively, such as physical therapy. As evidenced by multiple studies, the greatest positive impact on postoperative rehabilitation is an increase in physical activity. Wang et al. [17] showed that prehabilitation was responsible for decreased pain scores at 4 weeks in patients that underwent joint replacement surgeries, and had improved more on Western Ontario McMaster University's Osteoarthritis Index (WOMAC) scores and time to climbing stairs function than non-prehabilitated patients. Even more important, by establishing the PSH model, anesthesiologists will have greater opportunities to influence the functional outcomes and even be able, through individual planning, to choose selective regional anesthetic techniques or other pain modalities, as well as follow up with progress on inpatient wards. Pain is more costly than initially thought; $30 \%$ of patients reported severe pain in spite of narcotic use, but more importantly narcotic use is the rate-limiting step in patients regaining bowel movement, which in turn directly influences length of stay [18]. Note that this discussion does not even consider opioid induced adverse events in hospital.

\section{Goal directed fluid therapy}

This represents a judicious management initiative that has proven to have better outcomes in settings such as the ICU or in the management of cardiac patients. While there is still a gap in how anesthesiologists 
manage fluid administration perioperatively, a study published by Rollins \& Lobo showed a decrease in morbidity and length of stay with a significantly shorter intensive care length of stay for the patients that were on the enhanced recovery pathway [19]. This is complemented by another study, a 2012 meta-analysis of multiple studies from as early as 1988. As Zhan, Purcell, and Bush noted in their article, 3861 patients from 23 randomized controlled studies of fluid management strategies were reviewed showing highly different outcomes from those that had more liberal use of fluids and had a higher incidence of pneumonia, pulmonary oedema, and increase length of stay than those treated by goal directed therapy with the use of dynamic parameters [20]. The study also cited that goal directed therapy is more beneficial in patients undergoing major surgeries. While more studies are needed, there is evidence that goal directed therapy leads to improved outcomes in cardiac surgery, holding promise for patients undergoing non cardiac surgery as well [21].

Research shows that under/over fluid resuscitation is linked to an increased complications rate. With poor predictors such as advanced age, a lactate level of 2 $\mathrm{mmol} / \mathrm{L}$, central venous oxygen saturation of $70 \%$, or long surgeries [22], the goal directed therapy uses physiologic parameters such as stroke index volume variation through the use of Edwards flow tracks (most widely used in the US). The technique has proven to reduce mortality in sepsis patients and is the focus of $\mathrm{PSH}$, particularly aimed at high risk surgeries such as abdominal surgeries.

\section{Reducing length of stay and readmission rates}

Surgical care accounts for $40 \%$ of overall spending for inpatients making surgical services a priority for better quality and lower costs targets [23]. A Centre for Medicare and Medicaid Services report shows that $30 \%$ of patients are being readmitted within 30 days post-surgery, now subject to a $3 \%$ penalty (top causes for Medicare in academic centres are congestive heart failure (CHF), pneumonia and sepsis, while in private hospitals it is surgical complications and chemotherapy related complications) [24]. Decreasing preventable readmission is a top priority for hospitals and CMS as well since 17 billion in Medicare waste has been attributed to preventable readmissions, with 730 million in four states within a six-month period [25]. Determinants of preventable readmissions are variable and include patient comorbidities, infection, and a need for postoperative blood transfusions. As Weeks et al. showed in their study treating comorbidities that raise readmission rates early through integrated care and preoperative approaches, decreases readmission rates [26]. Ferraris et al. complemented those findings through a study of their own [27]; Ozturk et al. also emphasize the importance of optimizing preoperative comorbidities, again making PSH the best positioned strategy since it can not only coordinate optimization with other specialties, but most importantly it can customize the care plan for the patient [28]. This is of the utmost benefit for elderly patients, due to the group becoming increasingly larger, having a higher life expectancy, and being heterogeneous in terms of health status preoperatively. One such example is the optimization of beta blocker medication in vascular diseases from the study by Lindenauer et al. from 2005 [13].

As Carli et al. showed throughout their study, prehabilitation is the key to better outcomes in patients with colorectal malignancy, particularly increased strenuous physical activity. Elderly patients with malignancies are at risk of malnutrition [29]. Gravante \& Elmussareh cited in their study that $40 \%$ of hospitalized elderly with cancer have this risk, thus increasing length of stay, mortality and morbidity, as well as being an independent predictor of poor survival. Perioperative Surgical Home addresses nutritional support (Carli et al. recommend an increase in nutritional supplement up to $1.2 \mathrm{~g} / \mathrm{kg}$ of body weight) as well as integrating multimodal treatment to decrease anxiety or depression for patients, thus reducing length of stay and readmission rates [30].

Perioperative Surgical Home preoperative preparation would be focused on prevention of such readmissions through coordinated care, aggressive prehabilitation to prevent complications (incentive spirometry preoperatively to prevent pneumonia, optimize medication to prevent episodes of CHF in patients at risk for example). The frailty present in 1:5 patients over 65 years underscores the importance of nutritional support preoperatively.

\section{Cost control}

This represents an added goal for PSH. Opportunities for decreasing costs relate to working to eliminate unnecessary interventions, optimize staffing/assignments (best person for the job) and decrease cancellations, length of stay, and even OR times. As medical directors, anesthesiologists are uniquely positioned to help in this respect. For example, anesthesiologists will order only the needed preoperative tests and will be more likely to comply with multi societal guidelines, aided by the launching of the Choosing Wisely initiatives. The best example is limiting the use of imaging tests (no ordering of an echocardiogram in an otherwise healthy, asymptomatic, patient that has stable, known coronary artery disease). 
The Choosing Wisely campaign provides a tremendous opportunity, as it is evidence-based, has logical criteria, and establishes common clinical practices for patient testing when there is little or no benefit to the patient or when avoidance of testing would lead to either improved quality of care or decreased costs. The initiative has been founded through the support of seven different medical societies (including AMA, ASA, ACS) to provide guidance in the context of perioperative practice. The initiative is estimated to decrease costs by $\$ 80-180$ million [7].

Additionally, PSH responds to the needs that drivers of change have outlined, including patient dissatisfaction and inconvenience, the need to decrease payment models that reward volume, and decrease financial rewards for testing.

Aside from all the patient centred quality improvement initiatives it drives, PSH also has undeniable effects on efficiency in the OR. The initiative minimizes staffing, decreases overtime due to proper preparation of patients for surgery therefore reducing testing/ paperwork preoperatively, provides opportunity for inpatients (representing 20\% of patients) that are not electively scheduled to have appropriate access to the OR through appropriate preoperative preparation, and decreases administrative cancelation rates (lack of paperwork related cancellations).

While models differ among institutions, all PSH models have a service line set up that includes anesthesiologists well trained in data management strategies, nurses, and hospitalists, and surgeons. Most commonly they involve joint replacement service lines, oncologic service and vascular service lines with plans to add by coordinated expansion. As evidenced by the success of the institutions that have initiated early implementation of PSH, shows that the PSH model decreased case cancellations of day of surgery by $1-8 \%$, decreased costs by $40-59 \%$, increased surgical volume and flow by $20 \%$, and decreased cost per patient by $8-18 \%$. A study by Lee et al. shows a decreased length of stay highly dependent on the type of anesthetic? anesthesia? (lower in spinal anesthetized patients than in those that underwent general anesthesia) which was made possible by the early identification and customization of plans [31].

At my own institution we have now enrolled four service lines with a fifth already aligned for expansion, and while it is too early to have study outcomes available, we can report higher patient satisfaction expressed directly by patients to our providers.

Multiple drivers of healthcare are changing the landscape to value base (Centres for Medicare and Medicaid, commercial insurers, large employers and patients). The advent of the Medicare access chip reauthorization act of 2015 (MACRA) consolidates and expands merit based incentive payment system (MIPS). MIPS will be adjusting Medicare payments to hospital on a single budget neutral payment beginning in 2019. Hospitals will face incentives (negative incentives starting from up to $4 \%$ in 2019 incrementally increasing by 2022 to up to $9 \%$ ). Positive incentives will also incrementally increase from up to $12 \%$ in 2019 to up to $27 \%$ by 2022 . This is challenging both the practice model and scope. PSH must translate, implement, sustain document quality, safety and satisfaction improvement as well as deliver cost containment strategies. To accomplish this it has proposed decreasing practice variability and increasing its efficiency, assessing patient risk stratification and mitigation, optimizing perioperative comorbidities and educating and counselling patient preoperatively [32].

The importance of the PSH in the future of Anesthesiology is emphasized by the planned inclusion in the resident curriculum of aspects of perioperative care, particularly postoperative care, as well as waste decrease methodologies such as Lean Six Sigma combined with quality improvement methodologies such as root cause analysis (RCA) and failure mode and elimination analysis (FMEA).

Looking toward the future and adapting to new technologies and demands from patients, payers, and regulatory agencies are contributors to a complete change in our profession's landscape. As always, change is difficult and will need champions but it is ultimately our patients who will benefit from the cultural shift, and that is the true reward.

\section{Conflict of interest}

Nothing to declare

\section{References}

1. Kain ZN, Vakharia S, Garson L, Engwall S, Schwarzkopf R, Gupta R, et al. The perioperative surgical home as a future perioperative practice model. Anesth Analg 2014; 118: 11261130. DOI: 10.1213/ANE.0000000000000190

2. Partridge J, Harari D, Gossage J, Dhesi J. Anemia in older surgical patient: a review of prevalence, causes, implications and management. J R Soc Med 2013; 106: 269-277. DOI: $10.1177 /$ 0141076813479580

3. Marcantonio ER, Goldman L, Orav EJ, Cook EF, Lee TH. The association of intraoperative factors with the development of postoperative delirium. Am J Med 1998; 105: 380-384

4. Network for the Advancement of Patient Blood Management, Haemostasis and Thrombosis (NATA) [online]. 2016 [cited 2016 June 02]. Available from: www.nataonline.com. or http:// www.transfusionmedicine.ca/resources/links/weblinks/networkadvancement-transfusion-alternatives-nata

5. Na HS, Shin SY, Hwang JY, Jeon YT, Kim CS, Do SH. Effects of intravenous iron combined with low-dose recombinant human erythropoietin on transfusion requirements in iron-deficient 
patients undergoing bilateral total knee replacement arthroplasty. Transfusion 2011; 51: 118-124. DOI: 10.1111/ j. 1537-2995.2010.02783.x

6. Shander A, Hofmann A, Gombotz H, Theusinger OM, Spahn DR. Estimating the cost of blood: past, present and future. Best Pract Res Clin Anaesthesiol 2007; 21: 271-289

7. ABIM Foundation. Choosing Wisely [online]. 2015 [cited 2016 July 03]. Available from: www.choosingwisely.org

8. Browne JA, Adib F, Brown TE, Novicoff WM. Transfusion rates are increasing following total hip arthroplasty: risk factors and outcomes. J Arthroplasty 2013; 28(8 Suppl): 34-37. DOI: 10.1016/j.arth.2013.03.035

9. Clevenger B, Richards T. Pre-operative anaemia. Anaesthesia 2015; 70(Suppl 1): 20-28. DOI: 10.1111/anae.12918

10. Hubbard T, McNeill N. Improving medication adherence and reducing readmissions. Network for Excellence in Health Innovation (NEHI), Issue Brief 2012 Oct: 1-12

11. Centres for Medicare \& Medicaid Services. Partnership for patients [online]. [cited 2016 May 27]. Available from: https:/ /partnershipforpatients.cms.gov/

12. United States Department of Health and Human Services: Agency for Healthcare Research and Quality (AHRQ). Reducing and preventing adverse drug events to decrease hospital costs. Research in Action 1 [online]. [cited 2016 June 24]. Available from: http://archive.ahrq.gov/research/findings/factsheets/ errors-safety/aderia/ade.html

13. Lindenauer PK, Pekow P, Wang K, Mamidi DK, Gutierrez B, Benjamin EM. Perioperative beta-blocker therapy and mortality after major noncardiac surgery. N Engl J Med 2005: 353: 349361. DOI: 10.1056/NEJMoa041895

14. Administration on Aging, Administration for Community Living, U.S. Department of Health and Human Services. A profile on older Americans: 2011. Washington DC: Department of Health and Human Services; 2011: 1-16

15. DeVol R, Bedrossian A, eds. An Unhealthy America: The Economic Burden of Chronic Disease. Santa Monica, CA: Miliken Institute; 2007: 1-38

16. Leung JM, Sands LP, Lim E, Tsai TL, Kinjo S. Does preoperative risk for delirium moderate the effects of postoperative pain and opiate use on postoperative delirium? Am J Geriatr Psychiatry 2013; 21(10): 946-956. DOI: 10.1016/j.jagp.2013.01.069

17. Wang L, Lee M, Zhang Z, Moodie J, Cheng D, Martin J. Does preoperative rehabilitation for patients planning to undergo joint replacement surgery improve outcomes? A systematic review and meta-analysis of randomised controlled trials. BMJ Open 2016; 6: e0009857. DOI: 10.1136/bmjopen-2015-009857

18. Walters TL, Mariano ER, Clark JD. Perioperative surgical home and the integral role of pain medicine. Pain Med 2015; 16: 1666-1672. DOI: $10.1111 /$ pme.12796

19. Rollins KE, Lobo DN. Intraoperative goal-directed fluid therapy in elective major abdominal surgery. Ann Surg 2016; 263: 465476. DOI: $10.1097 /$ SLA. 0000000000001366

20. Zhan HT, Purcell ST, Bush RL. Preoperative optimization of vascular surgery patient. Vasc Health Risk Manag 2015; 11: 379-385. DOI: $10.2147 /$ VHRM.S83492

21. Aya HD, Cecconi M, Hamilton M, Rhodes A. Goal-directed therapy in cardiac surgery: a systematic review and meta-analysis. Br J Anesth 2013; 110: 510-517. DOI: 10.1093/bja/aet020

22. Marik PE, Monnet X, Teboul JL. Hemodynamic parameters to guide fluid therapy. Ann Intensive Care 2011; 1: 1. DOI: 10.1186/ 2110-5820-1-1

23. Cullen KA, Hall MJ, Golosinskiy A. Ambulatory surgery in the United States, 2006. Natl Health Stat Report 2009; (11): 1-25
24. Vest JR, Gamm LD, Oxford BA, Gonzalez MI, Slawson KM. Determinants of preventable readmissions in the United States: a systematic review. Implement Sci 2010; 5: 88. DOI: 10.1186/ 1748-5908-5-88

25. Weeks WB, Lee RE, Wallace AE, West AN, Bagian JP. Do older rural and urban veterans experience different rates of unplanned readmission to VA and non-VA hospitals? J Rural Health 2009; 25: 62-69. DOI: 10.1111/j.1748-0361.2009.00200.x

26. Ferraris VA, Ferraris SP, Harmon RC, Evans BD. Risk factors for early hospital readmission after cardiac operations. J Thorac Cardiovasc Surg 2001; 122: 278-286. DOI: 10.1067/ mtc.2001.114776

27. Ozturk E, Kiran RP, Remzi F, Fazio VW. Early readmission after ileoanal pouch surgery. Dis Colon Rectum 2009; 52: 18481853. DOI: 10.1007/DCR.0b013e3181b15610

28. Carli F, Awasthi R, Gillis C, Kassouf W. Optimizing a frail elderly patient for radical cystectomy with a prehabilitation program. Can Urol Assoc J 2014; 8(11-12): E884-887. DOI: 10.5489/ cuaj. 2025

29. Gravante G, Elmussareh M. Enhanced recovery for noncolorectal surgery. World J Gastroenterol 2012; 18: 205-211. DOI: $10.3748 /$ wjg.v18.i3.205

30. Reed SJ, Pearson S. Choosing Wisely recommendation analysis: prioritizing opportunities for reducing inappropriate care: imaging for uncomplicated headache. Institute for Clinical and Economic Review [online]. 2014 [cited 2016 June 20]. Available from: http://www.choosingwisely.org/wp-content/uploads/2015/ 05/ICER_Headache.pdf

31. Lee A, Kerridge RK, Chui PT, Chiu CH, Gin T. Perioperative Systems as a quality model of perioperative medicine and surgical care. Health Policy 2011; 102: 214-222. DOI: 10.1016/ j.healthpol.2011.05.009

32. Vetter TR, Goeddel LA, Boudreaux AM, et al. The Perioperative Surgical Home: how can it make the case so that everyone wins? BMC Anesthesiology 2013; 13: 6. DOI: 10.1186/14712253-13-6

\section{Îngrijirea perioperatorie - față în față cu provocările de mâine}

\section{Rezumat}

Noile modele de servicii medicale propun o varietate de modificări pentru anestezişti, de la nevoia de a îmbunătăti calitatea serviciilor la restrângerea costurilor, dezvoltând astfel conceptul de "Perioperative Surgical Home" (PSH).

Creat după modelul intensificării recuperării postoperatorii (ERAS), conceptul de PSH face un pas mai departe şi propune ca îngrijirea coordonată a pacientului, începută o dată cu decizia intervenției chirurgicale, să continue timp de 30 de zile postoperator, şi să fie precedată de o judicioasă evaluare preoperatorie bazată pe dovezile stabilite în literatura de specialitate.

PSH se bazează de asemenea în mare măsură pe ingineriile de strategie importate, cum ar fi metodologiile Lean Six Sigma, şi astfel implică participarea activă a tuturor organizațiilor administrative interesate direct. 
Prin comparație, ERAS reprezintă o sumă de protocoale clinice bine definite care nu se referă şi la perioada care depăşeşte episodul intervenției chirurgicale. Ca un beneficiu adițional PSH determină o îmbunătățire a controlului costurilor prin scăderea testelor care nu sunt necesare şi a contramandărilor de intervenții chirur- gicale determinând astfel un acces sporit în sălile de operații pentru pacienții internați.

Cuvinte cheie: intensificarea recuperării, îngrijire perioperatorie, managementul transfuziei şi al terapiei cu lichide, controlul durerii 